\title{
Geochemical traits of urban landscapes
}

\author{
V.A. Alekseenko \\ Doctor of geological and mineralogical Sciences, Institute for Water and Environmental Problems of Siberian \\ Branch of the Russian Academy of Sciences, Barnaul, Russia; \\ Southern Federal University, Rostov-on-Don, Russia; \\ Admiral Ushakov Maritime State University, Novorossiysk, Russia
}

N.V. Shvydkaya

Kuban State Agrarian University, Krasnodar, Russia

\begin{abstract}
A.V. Puzanov
Institute for Water and Environmental Problems of Siberian Branch of the Russian Academy of Sciences, Barnaul, Russia
\end{abstract}

A.V. Nastavkin

Southern Federal University, Rostov-on-Don, Russia

\begin{abstract}
The study examines environmental quality in residential landscapes. From the point of view of the migration of elements, urban landscapes are almost identical to industrial ones located beyond the city's borders. The greater impact on all residents - not only on the employees of an enterprise - is the key environmental difference that should be emphasized. In addition, pollutants, especially aerosols, are dispersed less effectively in cities than outside them. Considering these landscapes, it should be borne in mind that very peculiar pollution types like electromagnetic, thermal, sound (noise), and radioactive can occur in the course of life activities within a city. These pollution types cause certain environmental changes as well. For large-scale studies conducted in megacities, as well as for ecological and geochemical certification, a more detailed classification of landscapes is required. Patterns of technogenic migration and concentration of chemical elements are still the basis of division in these cases.
\end{abstract}

\section{INTRODUCTION}

Classification of urban geochemical landscapes is carried out taking into account the characteristics of the leading type of migration of chemical elements, i.e. the technogenic patterns. On this basis, first of all, landscapes of industrial, residential, and recreational areas, streets, military zones, wastelands, and cemeteries are distinguished. Industrial landscapes include territories located within localities and occupied by various production enterprises (factories and their separate workshops, transport parks, power plants, etc.), and in certain cases quarries and underground mines (Ajmone-Marsan \& Biasioli 2010; Bech et al. 2015; Ermolin et al. 2017; Gallagher et al. 2008; Ngun et al. 2018; Tepanosyan et al. 2019). The same landscapes include territories occupied by buildings necessary for the operation of the named enterprises.

First of all, it is advisable to separate out the landscapes of quarries and underground mines, dumps of mine workings, various factories, power plants, garages, tram and trolleybus parks, gas stations, waste processing facilities, bazaars, as well as the landscapes of automobile and railway stations, airports, and river and seaports. All of them differ from each other in the composition, occurrence form and amount of pollutants, both distributed within their limits, and in neighboring landscapes of a locality. 
Landscapes of residential areas normally take a major part of settlements (Grebenshchikova et al. 2017; Naylo et al. 2019; Seleznev et al. 2019; Timofeev et al. 2019). In addition, a significant share of residents spends most of their lives there. Therefore, the assessment of the ecological and geochemical situation of such zones and its improvement are among the most important environmental issues.

Quite often, biological cycles of elements play a significant role in the evolution of landscapes in residential areas. This is especially true for small settlements with one-story houses and homesteads. However, the biological cycles in residential areas of cities differ significantly from those in neighboring industrial, recreational and other urban landscapes (KabataPendias \& Pendias 2001).

The building height in residential areas, directly and indirectly, affects the pathways of numerous chemical elements and compounds that end up being accumulated or removed from the urban environment. Wind direction and speed, as well as the ratio of turbulent and laminar air flows, are also often dependent on the number of stories. All other things being equal, these indicators become decisive for the content of many substances, including toxic ones, in the air, and consequently for the ingress from it into soils, plant and animal organisms (including humans).

The number of floors alters the density of the population in a residential area; the volume of municipal waste and ways of disposal are associated with it too. Stories largely determine water supply and heating, which, in turn, control the input and removal of not only elements in the form of solutions and gas mixtures, but also elements in other forms. Species diversity and the number of domestic animals also largely depend on this indicator, and consequently, the features of migration, and often the forms of chemical elements in the landscapes of residential areas. The number of floors in residential areas also affects the level of comfort of residents living in them, as well as the speed and level of spread of various infections and even specific diseases (often mental disorders). These features largely determine the ecological status of many areas.

\section{MATERIALS AND METHODS}

Field studies in urban areas were carried out during the summer seasons with sampling the upper $(0-5 \mathrm{~cm})$ horizon of soils and technogenic superficial formations, which is the most indicative part of the soil cover from the point of view of pollution - the depositing geochemical environment. The work was carried out following a regular grid with a step of $1 \mathrm{~km}$, which is the most representative in the field research conditions, covering all the main geochemical landscapes of the research area. Soil sections were studied within the residential urban parts, with a description of the horizons and sampling. The full list of the studied urban areas categorized by population or primary component of the local economy includes cities with the number of citizens equal to over 1 million, half a million, over 100 thousand, and less than 100 thousand, as well as resort towns and villages of agricultural specialization (Alekseenko \& Alekseenko 2014).

The combination of buildings of different height in the landscapes of residential zones can be considered as a main ecological and geochemical indicator for them. In accordance with this indicator, the considered landscapes should be divided more detailed for special studies. It should be noted that in recent years, in many cities, development is conducted on the principle of creating neighborhoods with a specific combination and mutual location of buildings of different stories. When detailing these areas, it is advisable to consider them as separate landscapes. Their ecological and geochemical features should be taken into account when developing the research methodology.

The study of surface horizons of soils was carried out according to the method of an averaged sample: the soil was collected at least three times from the laid-down digs with a depth of $0-5 \mathrm{~cm}$ on a plot of approximately $10 \mathrm{sq} . \mathrm{m}$, samples were placed in a single package, their total weight was about $3 \mathrm{~kg}$. Mixing and averaging were performed in the laboratory. The analyses of soil and plant samples were carried out in the certified and accredited Central Testing Laboratory at Kavkazgeolsyomka using emission spectral analysis. 


\section{RESULTS}

Streets are the closest in geochemical features to roads that are allocated outside of localities, and also have no natural analogs. These include roadways and sidewalks (often with plantings of various bushes and trees) near residential buildings, industrial enterprises or barriers that fence off homesteads or other landscapes of the locality. Despite the usual plantings along sidewalks, biological cycles are low-developed in the considered landscapes, since all the fall and dry branches of trees and shrubs, as a rule, are taken out of a city or burned, and the ash is most often dispersed, not concentrating in the street landscapes.

As in other landscapes of settlements, a significant part of the elements in the street comes through the atmosphere. At the same time, unlike neighboring landscapes, car exhaust gases play a significant role in the atmospheric air of streets. They are also the most toxic compounds that are constantly present in the atmospheric gases on the streets. Their concentration is related to the traffic intensity. The latter is largely responsible for the dustiness and receipt of specific compounds in the described landscapes due to the wear of tires, engines, tram tracks, etc.

Indirectly, the traffic intensity is related to the type of road surface (paved, unpaved, etc.). Special cases are streets where railway traffic occurs; in such landscapes, the flow of chemical elements is unpredictable, in various forms: although in relatively small quantities due to spilling out of the cars.

There is usually no significant accumulation of substances from neighboring landscapes on the streets. They themselves are a source of numerous compounds that enter the surrounding landscapes through the atmosphere. The height of buildings that limit streets, as well as the plantings and the type of plants that make up them, have a great influence on this movement of elements. A significant share of different substances is removed from the streets by surface and underground water. They can be concentrated on certain geochemical barriers, creating technogenic anomalies (Table 1) that are not associated with any enterprises, which must be taken into account when making special maps for ecological and geochemical studies.

Table 1. Comparison of the average contents of a number of chemical elements in the soils of various groups of settlements.

\begin{tabular}{|c|c|c|c|c|}
\hline \multirow{2}{*}{$\begin{array}{l}\text { Categories of urban areas } \\
\text { by population or primary } \\
\text { component of the local } \\
\text { economy }\end{array}$} & \multicolumn{2}{|c|}{ Heightened average contents } & \multicolumn{2}{|c|}{ Decreased average contents } \\
\hline & $\begin{array}{l}\text { Number of } \\
\text { elements }\end{array}$ & Elements & $\begin{array}{l}\text { Number of } \\
\text { elements }\end{array}$ & Elements \\
\hline Over 1 million population & 17 & $\begin{array}{l}\mathrm{Ag}, \mathrm{As}, \mathrm{Be}, \mathrm{Bi}, \mathrm{Cd}, \\
\mathrm{Co}, \mathrm{Cr}, \mathrm{Cu}, \mathrm{Ga}, \mathrm{Mn}, \\
\mathrm{Ni}, \mathrm{P}, \mathrm{Pb}, \mathrm{Sn}, \mathrm{Ti}, \mathrm{V}, \\
\text { and } \mathrm{Zn}\end{array}$ & 2 & $\mathrm{Li}$ and $\mathrm{W}$ \\
\hline Half a million population & 4 & $\mathrm{Ba}, \mathrm{La}, \mathrm{Li}$, and $\mathrm{W}$ & 11 & $\begin{array}{l}\mathrm{Ag}, \mathrm{As}, \mathrm{Mo}, \mathrm{Nb}, \mathrm{P}, \mathrm{Sc}, \\
\mathrm{Sn}, \mathrm{Ti}, \mathrm{Tl}, \mathrm{V}, \text { and } \mathrm{Yb}\end{array}$ \\
\hline $\begin{array}{l}\text { Over } 100 \text { thousand } \\
\text { population }\end{array}$ & 11 & $\begin{array}{l}\mathrm{Ag}, \mathrm{Bi}, \mathrm{Mo}, \mathrm{Nb}, \mathrm{P}, \mathrm{Sn} \\
\mathrm{Sr}, \mathrm{W}, \mathrm{Y}, \mathrm{Yb} \text {, and } \mathrm{Zr}\end{array}$ & 10 & $\begin{array}{l}\mathrm{Ba}, \mathrm{Cd}, \mathrm{Co}, \mathrm{Cr}, \mathrm{Cu} \text {, } \\
\mathrm{Ga}, \mathrm{Ge}, \mathrm{Mn}, \mathrm{Ni} \text {, and } \\
\mathrm{Ti}\end{array}$ \\
\hline $\begin{array}{l}\text { Less than } 100 \text { thousand } \\
\text { population }\end{array}$ & 7 & $\begin{array}{l}\mathrm{Ge}, \mathrm{Nb}, \mathrm{Se}, \mathrm{Tl}, \mathrm{Y}, \mathrm{Yb} \text {, } \\
\text { and } \mathrm{Zr}\end{array}$ & 10 & $\begin{array}{l}\mathrm{Be}, \mathrm{Bi}, \mathrm{Cu}, \mathrm{Ga}, \mathrm{Li}, \\
\mathrm{Mn}, \mathrm{Ni}, \mathrm{Pb}, \mathrm{Sr} \text {, and } \mathrm{Zn}\end{array}$ \\
\hline Resort towns & 16 & $\begin{array}{l}\mathrm{As}, \mathrm{Ba}, \mathrm{Cd}, \mathrm{Co}, \mathrm{Cr}, \\
\mathrm{Cu}, \mathrm{Ge}, \mathrm{Li}, \mathrm{Mn}, \mathrm{Ni} \\
\mathrm{Pb}, \mathrm{Sc}, \mathrm{Sr}, \mathrm{Tl}, \mathrm{V} \text {, and } \\
\mathrm{Zn}\end{array}$ & 6 & $\begin{array}{l}\text { Mo, P, W, Y, Yb, and } \\
\mathrm{Zr}\end{array}$ \\
\hline $\begin{array}{l}\text { Villages of agricultural } \\
\text { specialization }\end{array}$ & 4 & $\mathrm{Be}, \mathrm{Ga}, \mathrm{Mo}$, and $\mathrm{Ti}$ & 18 & $\begin{array}{l}\mathrm{Ag}, \mathrm{As}, \mathrm{Ba}, \mathrm{Bi}, \mathrm{Cd}, \mathrm{Co}, \\
\mathrm{Cr}, \mathrm{Ge}, \mathrm{Nb}, \mathrm{Pb}, \mathrm{Sc}, \mathrm{Sn} \\
\mathrm{Sr}, \mathrm{Tl}, \mathrm{V}, \mathrm{Y}, \mathrm{Zn}, \text { and } \mathrm{Zr}\end{array}$ \\
\hline
\end{tabular}


In the case of special and detailed studies, it is advisable to separate street landscapes taking into account the traffic intensity, the prevailing mode of transport, and the characteristics of the road surface.

Landscapes of recreation areas are located both in the center and on the outskirts of settlements. These include parks, stadiums, squares, sports fields, alleys, recreation lines along banks of rivers, reservoirs, seas, etc. Biological properties of some of them (parks, squares, etc.) are close to the forest-engineering landscapes that are allocated outside of settlements. The landscapes under consideration do not receive any specific compounds, except for oxygen and various solid, liquid and gaseous products of life activity of organisms. Most of the substances entering the recreation areas are transported by air from nearby localities (Mazhari et al. 2018). In recent years, pollution of these landscapes by exhaust fumes from cars and motorboats has become widespread.

For urban areas, especially large ones, very important environmental indicators are the percentage of city's territory occupied by recreation areas, and the uniformity of distribution of the latter over the entire area of the city.

The landscapes of zones occupied by military departments are currently among the least studied. The specific environmental pollution caused by them and the need for their ecological and geochemical study has been discussed only recently, in connection with the withdrawal of troops from Eastern Europe.

In addition to the actual environmental and geochemical pollution, they can cause radiation, electromagnetic, noise, heat, and other types of environmental pollution. Therefore, such landscapes should be highlighted even if they are small and impossible to study. Their classification has not been developed yet for large-scale and detailed studies.

\section{DISCUSSION}

The relationship between the content of most chemical elements in soils - including metals with the development of living organisms and the concentration of these elements in them is considered in several works (Bourotte et al. 2019; Lenoir et al. 2019; Tepanosyan et al. 2017). We note only that, as when studying other landscapes, the following factors must be taken into account in urban areas at this level:

- redox conditions, oxidizing with free oxygen and reducing with either gley or sulfides;

- alkaline-acid conditions, which are best divided as strongly acidic, acidic, neutral, and highly alkaline;

- a set of typomorphic elements and, as a result, a class of water migration of chemical elements.

Quite often, especially for detailed work, in the conditions of urban landscapes, the considered selection is not enough. In such cases, a set of typomorphic elements in groundwater should be considered at the same level. It is advisable to note the alkaline-acid properties of groundwater and the acid-sulfur regime, since these indicators in the waters and soils of different parts of settlements may differ very significantly and represent significant ecological and geochemical changes.

Urban landscapes are combined taking into account the geomorphological features of a territory. In terms of the land topography, it is convenient to combine eluvial, trans-eluvial, trans-accumulative, and accumulative positions. First of all, they differ from each other in the features of the mechanical migration of elements and their compounds. Moreover, additional maps of the material's surface drift are often required.

Wasteland landscapes have been developed in many localities. Their appearance is usually associated either with the demolition of old buildings, or with the reconstruction of cities, or with uneven development of certain areas, which usually leave empty areas for a short time. In the first case, landscapes (especially in old cities) may have a large geochemical diversity. However, as a rule, the main ecological and geochemical impact on neighboring urban landscapes is not caused by them, but by the construction waste that is brought from them. Quite 
often, vacant lots themselves become temporary storage areas for a variety of garbage - from household waste to construction debris. In this case, they should be given great attention, studying them as a kind of social geochemical barriers.

Cemetery landscapes can be divided into old and operating ones. Old cemeteries are usually located next to a city center and are similar to the landscapes of recreation areas in terms of their ecological and geochemical features. When designing new cemeteries, first of all, one should pay attention to the surface and underground water flow from them. It should not take place in the direction of existing or projected urban districts.

Among the urban landscapes of almost all localities, there are various educational institutions, kindergartens, hospitals, and public baths (Bourotte et al. 2019; Famuyiwa et al. 2019). When assessing the overall environmental situation in localities, special attention should be paid to both their number and the uniformity of distribution. On maps of urban geochemical landscapes, all these institutions should be marked with extra-scale signs.

The second taxonomic level is not less important. At this level, despite the practical poor development of biological cycles in localities, it is advisable to combine urban landscapes based on the characteristics of plant communities and their preservation. There are two main reasons for this.

First, plants are very sensitive to changes not only in the complex of ecological and geochemical conditions but also in such important indicators for normal human life as radiation conditions, thermal pollution, etc. Based on the state (or even survival) of certain plant species (Bezel' et al. 2015; Drozdova et al. 2019; Yalaltdinova et al. 2018), it is often possible to pre-judge changes in the urban environment without analyses, which are sometimes rather expensive.

Secondly, in many localities, especially with a small number of residents, a significant part of agricultural products (fruits, vegetables, and various herbs for vegetable seasonings) is supplied from homesteads. In order to avoid poisoning and to obtain environmentally friendly products, areas with certain agricultural crops located within the boundaries of a city should be identified and their geochemical features studied in detail.

Detailed and special ecological and geochemical studies often require a more fractional division of landscapes. In these cases, one can select separate landscapes with certain agricultural crops, both perennial and annual, ornamental plants, or with their various combinations. In addition, for special studies, separate maps of the sanitary state of plantings should usually be drawn up (Famuyiwa et al. 2019; Grebenshchikova et al. 2017; Tume et al. 2018).

\section{CONCLUSIONS}

Geochemical traits of natural landscapes are constantly affecting the urban environment. The study of landscapes is performed following the developed scheme, depending on the composition of the rocks. However, when compiling ecological and geochemical maps of localities at the considered level, it is necessary to take into account the thickness of loose formations located between bedrock and soil, as well as the position of zones of discontinuous disturbances. These factors can be crucial in the design of residential and industrial buildings, especially in unstable environments.

The certain associations of plants were also affected by the background elements concentrations in soils of several cities. The increased concentrations of elements were more often detected other things being equal - in the landscapes with mixed decorative fruit and berry plant association $(\mathrm{Cu}, \mathrm{Pb}, \mathrm{Co}, \mathrm{Mn}, \mathrm{Ti}, \mathrm{Sr})$, less often - with agricultural fruit and berry plant association ( $\mathrm{Zn}, \mathrm{Ag}, \mathrm{Sn}, \mathrm{Ba}, \mathrm{Cr}$ ). In parks with just decorative kinds of plants, the increased concentrations of $\mathrm{V}$ and $\mathrm{Sc}$ were identified. The traffic intensity could also have some influence in this case.

\section{ACKNOWLEDGMENTS}

The analyses of soil and plant samples were carried out in the certified and accredited Central Testing Laboratory at Kavkazgeolsyomka using emission spectral analysis. 


\section{REFERENCES}

Ajmone-Marsan, F. \& Biasioli, M. 2010. Trace elements in soils of urban areas. Water Air and Soil Pollution $213,121-143$.

Alekseenko, V. \& Alekseenko, A. 2014. The abundances of chemical elements in urban soils. Journal of Geochemical Exploration 147 (B), 245-249.

Bech, J., Tume, P., Roca, N. \& Reverter, F. 2015. Geochemical distribution of potentially harmful elements in periurban soils of a Mediterranean region: Manresa (Catalonia, Spain). Fresenius Environmental Bulletin 24(12A), 4379-4389.

Bezel', V.S., Zhuikova, T.V. \& Gordeeva, V.A. 2015. Geochemistry of grass biocenoses: Biogenic cycles of chemical elements at contamination of the environment with heavy metals. Geochemistry International 53(3), 241-252.

Bourotte, C.L.M., Sugauara, L.E., De Marchi, M.R.R. \& Souto-Oliveira C.E. 2019. Trace metals and PAHs in topsoils of the university campus in the megacity of São Paulo, Brazil. Anais da Academia Brasileira de Ciencias 91(3), 20180334.

Drozdova, I., Alekseeva-Popova, N., Dorofeyev, V., Bech, J., Belyaeva, A. \& Roca, N. 2019. A comparative study of the accumulation of trace elements in Brassicaceae plant species with phytoremediation potential. Applied Geochemistry 108, 104377.

Ermolin, M.S., Fedotov, P.S., Ivaneev, A.I., Fedyunina, N.N. \& Eskina, V.V. 2017. Isolation and quantitative analysis of road dust nanoparticles. Journal of Analytical Chemistry 72(5), 520-532.

Famuyiwa, A.O., Davidson, C.M., Oyeyiola, A.O., Lanre-Iyanda, Y. \& Babajide, S.O. 2019. Pollution characteristics and health risk assessment of potentially toxic elements in school playground soils: A case study of Lagos, Nigeria. Human and Ecological Risk Assessment 25(7), 1729-1744.

Gallagher F.J. 2008. Soil metal concentrations and vegetative assemblage structure in an urban brownfield. Environ Pollut 153, 351-361.

Grebenshchikova, V.I., Efimova, N.V. \& Doroshkov, A.A. 2017. Chemical composition of snow and soil in Svirsk city (Irkutsk Region, Pribaikal'e). Environmental Earth Sciences 76(20), 712.

Grebenshchikova, V.I., Gritsko, P.P., Kuznetsov, P.V. \& Doroshkov, A.A. 2017. Uranium and thorium in soil cover of the Irkutsk-Angarsk industrial zone (Baikal region). Bulletin of the Tomsk Polytechnic University, Geo Assets Engineering 328(7), 93-104.

Kabata-Pendias, A. \& Pendias, H. 2001. Trace elements in soils and plants. CRC Press LLC, Boca Raton.

Lenoir, T., Duc, M., Lassabatere, L. \& Bellagh, K. 2019. Identification of the artifact contribution to two urban Technosols by coupling a sorting test, chemical analyses, and a least absolute residual procedure. Journal of Soils and Sediments 19(2), 683-701.

Mazhari, S.A., Bajestani, A.R.M., Hatefi, F., Aliabadi, K. \& Haghighi, F. 2018. Soil geochemistry as a tool for the origin investigation and environmental evaluation of urban parks in Mashhad city, NE of Iran. Environmental Earth Sciences 77(13), 492.

Naylo, A., Almeida Pereira, S.I., Benidire, L., Schwartz, C. \& Boularbah, A. 2019. Trace and major element contents, microbial communities, and enzymatic activities of urban soils of Marrakech city along an anthropization gradient. Journal of Soils and Sediments 19(5), 2153-2165.

Ngun, C.T., Pleshakova, Y.V. \& Reshetnikov, M.V. 2018. Soil diagnosis of an urban settlement with low levels of anthropogenic pollution (Stepnoe, Saratov region). IOP Conference Series: Earth and Environmental Science 012067.

Seleznev, A., Yarmoshenko, I., Malinovsky, G., Kiseleva, D. \& Gulyaeva, T. 2019. Snow-dirt sludge as an indicator of environmental and sedimentation processes in the urban environment. Scientific Reports 9(1), 17241.

Tepanosyan, G., Sahakyan, L., Belyaeva, O., Maghakyan, N. \& Saghatelyan, A. 2017. Human health risk assessment and riskiest heavy metal origin identification in urban soils of Yerevan, Armenia. Chemosphere 184, 1230-1240.

Tepanosyan, G., Sahakyan, L., Zhang, C. \& Saghatelyan A. 2019. The application of Local Moran's I to identify spatial clusters and hot spots of $\mathrm{Pb}, \mathrm{Mo}$ and $\mathrm{Ti}$ in urban soils of Yerevan. Applied Geochemistry $104,116-123$.

Timofeev, I., Kosheleva, N. \& Kasimov, N. 2019. Health risk assessment based on the contents of potentially toxic elements in urban soils of Darkhan, Mongolia. Journal of Environmental Management 242, 279-289.

Tume, P., Roca, N., Rubio, R., King, R. \& Bech, J. 2018. An assessment of the potentially hazardous element contamination in urban soils of Arica, Chile. Journal of Geochemical Exploration 184, 345-357.

Yalaltdinova, A., Kim, J., Baranovskaya, N. \& Rikhvanov L. 2018. Populus nigra L. as a bioindicator of atmospheric trace element pollution and potential toxic impacts on human and ecosystem. Ecological Indicators 95, 974-983. 